\title{
Trends of Sustainable Residential Architecture
}

\author{
Arturas Narvydas, Kaunas University of Technology
}

\begin{abstract}
The article is based on Master's research conducted during Scottish Housing Expo 2010. The aim of the research was to determine the prevailing trends in sustainable residential architecture. Each trend can be described by features detected during visual and technical observation of project data. Based on that architects may predict possible problems related to a specific trend.
\end{abstract}

\section{Keywords - Sustainability, sustainable residential architecture.}

Development in the second half of the 20th century stressed the issues related to the environment and sustainability. It has been calculated that the construction sector of global economy annually consumes $50 \%$ of the total world energy resources and $21 \%$ of this volume is used in residential construction [1] J. Wines states that construction of housing consumes one-sixth of the world's fresh water supply, one quarter of its wood harvest, and two fifths of its fossil fuels and manufactured materials. As a result, architecture has become one of the primary targets of ecological reform [2].

J. Wines states that sustainable architecture reflects the Age of Green Technology, just as "architecture in the $20^{\text {th }}$ century began a celebration of Age of Industry and Technology". $\mathrm{He}$ stresses the necessity of creative dialog for opening ideas and identifying new directions in green design. [2] Thus, the research on sustainable housing expression and its aesthetics becomes relevant and is aimed to develop a wider framework of scientific understanding.

The aim of this article was to create a model of evaluation of sustainable residential architecture based on six prevailing trends. During the research, main features of sustainable housing were formulated. The purpose of such differentiation was to find out how different features of sustainable housing are represented in each trend. It was also important to estimate possible environmental impact and predominant site setting.

\section{Methodology of Research}

In order to better understand the subject, complex methodology of the research was developed. The whole research consists of several steps:

1) Analysis of literature - trends and features of sustainable residential architecture were identified;

2) On-site research of sustainable homes both in Lithuania and abroad;

3) Sustainable residential features were estimated according to special assessment scheme;

4) In addition, the following features were analyzed: predominate project setting, visual quality, relationship between the building and its setting and environmental impact;

5) Analysis of gathered data and identification of conceptual trends was performed;

\section{Definition of Sustainable Residential Architecture}

\section{A. Definition of Sustainable Housing and its Objectives}

Expression of sustainable housing has derived from the definition of sustainability formulated by the United Nations and is based on three key aspects of sustainable development: environmental, social and economic dimensions. The following principles of sustainable construction have been defined: rational use of resources, usage of ecological materials, creating healthy and safe environment, social cohesion and social justice, quality of life, cultural diversity, economic welfare and etc. This can be expressed using a diagram indicating three pillars of sustainability [3] (see Fig. 1).

On the other hand, sustainable residential architecture is fostered by objectives of sustainable development, such as: high quality of architecture, compact urban development, social diversity, economic development and ecology. High quality architecture is understood as innovative and up-to-date. It respects the heritage of the past and meets the needs of the present. Contemporary architecture should avoid all forms of pseudo-historical design. [4] Compact urban development stands for rational urbanism, multifunctional use of buildings and prevents urban sprawl. [5] Also it is important to create socially diverse environment where accessibility of housing contributes to social cohesion, economic development and ecology [3]. Accessibility here is meant as a possibility to have appropriate housing for people of every social background, especially considering socially vulnerable groups.

Moreover, construction process must be regulated by institutional management, which includes development of sustainable strategies, public education, legal and administrative control. During the implementation of sustainable strategies (national, regional, municipal), the foundation for future development is laid. Public education allows the society itself respond to the on-going process of urban development and create socially responsible projects. Legal regulation defines essential constraints and ensures the quality of the surrounding areas. Meanwhile, administrative regulation ensures supervision of exact project implementation and provides the system of financial support for environmentally-friendly construction [3] (see Fig. 2).

\section{B. Problems Related to Sustainable Housing Design}

Research of this topic revealed that during the last two decades quite a lot of different examples of sustainable residential buildings have emerged. However, no classification in terms of their architectural expression has been done, which would show how various features of sustainability are displayed and how different types of buildings affect their surrounding environment.

It is noted that among various projects realized the common problem of aesthetics and conceptuality occurred. J. Wines states that the main problem with green architecture is conflict between having a strong sense of commitment to ecological design that ends up in failure to convert noble objectives into an equivalent artistic expression [2]. 


\section{PRINCIPLES OF SUSTAINABLITY IN CONSTRUCTION}

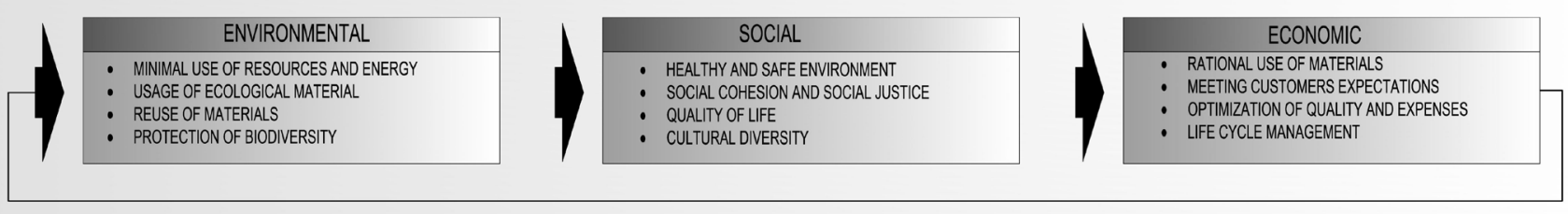

Fig. 1. Relationship between different principles of sustainability in construction.

\begin{tabular}{|c|c|c|c|c|}
\hline \multicolumn{5}{|c|}{ OBJECTIVES OF SUSTAINABLE DEVELOPMENT } \\
\hline $\begin{array}{l}\text { HIGH QUALITY OF ARCHITECTURE: } \\
\text { - MEETS THE NEED OF TODAY } \\
\text { - IS HIGH QUALITY AND UP TO DATE } \\
\text { - RESPECTS HERITAGE } \\
\text { - LOOKS HARMONIOUSLY IN ITS ENVIRONMENT } \\
\text { - IS INNOVATIVE IN ITS EXPRESSION AND USED TECHNOLOGY } \\
\text { - HUMAN SCALE } \\
\text { - COMFORTABLE AND SAFE }\end{array}$ & $\begin{array}{l}\text { COMPACT URBAN DEVELOPMENT: } \\
\text { - RATIONAL CONSTRUCTION } \\
\text { - MULTIIUNCTIONAL USE } \\
\text { - NEW BUILDINGS INTEGRATED IN EXISTING } \\
\text { CITY STRUCTURE } \\
\text { - EFFECTIVE USE OF TERRITORY } \\
\text { - PUBLIC TRANSPORT ACCEPTABILITY }\end{array}$ & $\begin{array}{l}\text { SOCIAL DIVERSITY: } \\
\text { - FUNCTIONAL ADOPTION OF SPACE } \\
\text { - SOCIAL DIVERSITY } \\
\text { - CREATION OF PUBLIC SPACES } \\
\text { - NEIGHBORHOOD DEVELOPMENT } \\
\text { - CREATION THE STATE OF COMMUNITY }\end{array}$ & $\begin{array}{l}\text { ECONOMIC DEVELOPMENT: } \\
\text { - DEVELOPMENT OF BUSINESS } \\
\text { INFRASTRUCTURE } \\
\text { - CONSTRUCTION OF WORK ENVIRONMENT } \\
\text { - RATIONAL CONSTRUCTION }\end{array}$ & $\begin{array}{l}\text { ECOLOGY: } \\
\text { - ECONOMICAL USE OF ENERGY AND MATERIALS } \\
\text { - USE OF ECOLOGICAL BUILDING MATERIALS } \\
\text { - VERTICAL GARDENS } \\
\text { - USE OF NATURAL ELEMENTS } \\
\text { - GRAY WATER PURIFICATION } \\
\text { - RAIN WATER COLLECTION AND REUSE }\end{array}$ \\
\hline
\end{tabular}

\begin{tabular}{|c|c|c|c|}
\hline \multicolumn{4}{|c|}{ INSTITUTIONAL MANAGEMENT } \\
\hline $\begin{array}{l}\text { DEVELOPMENT OF SUSTAINABLE STRATEGIES } \\
\text { - NATIONAL STRATEGIC PLANS } \\
\text { - REGIONAL PLANS OF EXPANSION AND } \\
\text { TRANSFORMATION } \\
\text { - MUNICIPAL PLANS OF DEVELOPMENT }\end{array}$ & $\begin{array}{l}\text { PUBLIC EDUCATION } \\
\text { - PROMOTION OF BENEFITS OF SUSTAINABLE } \\
\text { ARCHITECTURE } \\
\text { - SPREADING INFORMATION ABOUT ONGOING } \\
\text { SUSTAINABLE PROJECTS } \\
\text { - PROPORTION OF SUSTAINABLE WAY OF LIFE }\end{array}$ & $\begin{array}{l}\text { LEGAL CONTROL } \\
\text { - TERRITORIAL PLANING DOCUMENTS } \\
\text { - REGULATIONS } \\
\text { - BUILDING CODE RESTRICTIONS } \\
\text { - GENERAL DOCUMENTS DESCRIBING SUSTAINABLE } \\
\text { DEVELOPMENT }\end{array}$ & $\begin{array}{l}\text { ADMINISTRATINAL CONTROL } \\
\text { - MONITORING OF SUSTAINABLE PLAN } \\
\text { IMPLEMENTATION } \\
\text { - SANCTIONS AND FINES FOR DISOBEDIENCE OF } \\
\text { SUSTAINABLE PLANS } \\
\text { - FINANCIAL SUPPORT CONTRIBUTION FOR } \\
\text { QUALIFYING PROJECTS }\end{array}$ \\
\hline
\end{tabular}

Fig. 2. Objectives of sustainable housing construction.

Furthermore, a number of sustainable buildings are built mostly in rural areas. A lot of them represent countryside architecture, with some particular examples of regional features, such as thatched roofs, timber walls or clay floors. However, such ecocentric vernacular architecture may seem to confuse rather than reinforce a progressive image of sustainable housing design [5].

In general, the failures of industrial age call architects for the commitment to unite in a common cause of sustainable housing development on a more profound level. Sustainable residential architecture should not only be functional, economical and use renewable energy resources, it should also be aesthetically pleasing, psychologically acceptable and stay in harmony with environment. The latter features must become an integral part of sustainable development.

\section{Principles of Sustainable Housing Construction}

In 1994, the Counseil International du Batiment defined seven Principles of Sustainable Construction: reduction of resource consumption, reusing of resources, material recycling, protecting the nature, elimination of toxins, applying life-cycle cost and focusing on quality [6]. The following aspects must be implemented in the planning process and remain important during the entire life cycle [5].

Planning stage is the most important part of residential construction because the level sustainability is determined. During this stage, the main requirements for certain projects are underplayed and the whole expression of exact building is created. [5] Good green building design relies on the use of renewable resources, innovations and other approaches that minimize environmental impact. The comprehensive assessment of economic benefits, i.e. life-cycle cost analysis, must also be applied [3].

Moreover, sustainable residential architecture should also be aesthetical and provide harmonious development for the society (promote social cohesion and contribute to higher quality of life). Psychological acceptability, contextuality and relationship with surrounding environment must be perceived as integral part of sustainable residential building. Connection between physical and social environment of sustainable architecture is mutual: sustainable architecture promotes sustainable development as sustainable development creates favorable environment for further ideas of harmonious architecture [5].

In general, sustainable housing construction can be described by a scheme representing four main parts of building life cycle: creation, realization, existence and end of existence. Building creation consists of two main subcategories: planning (the most important stage of the construction process when the principles of sustainability are implemented) and design (preparation of drawings and verification of design documents). Building realization part consists of siting (site preparation) and construction. Building existence is basically the usage and maintenance of the building. The last part of building life cycle is demolition and recycling of building materials (see Fig. 3).

\section{Scientific Framework of Sustainable Housing}

Scientific framework included a variety of residential house designs and technologies ranging from the buildings built from the recycled materials like Straw House in London [7] to sophisticated projects of future cities, like Xiging city project in China, created by famous American architect Michael Sorkin. [8] Comprehensive analysis of different sustainable housing projects proposed the idea that they all can be classified into six trends according to their features detected during project observation, such as social, ecological, technological, economic, aesthetic and organic. 


\section{DEVELOPMENT OF SUSTAINABLE HOUSING PROJECT - PRINCIPLES OF SUSTAINABILITY ARE IMPLEMENTED IN WHOLE LIFE CYCLE OF THE PROJECT}
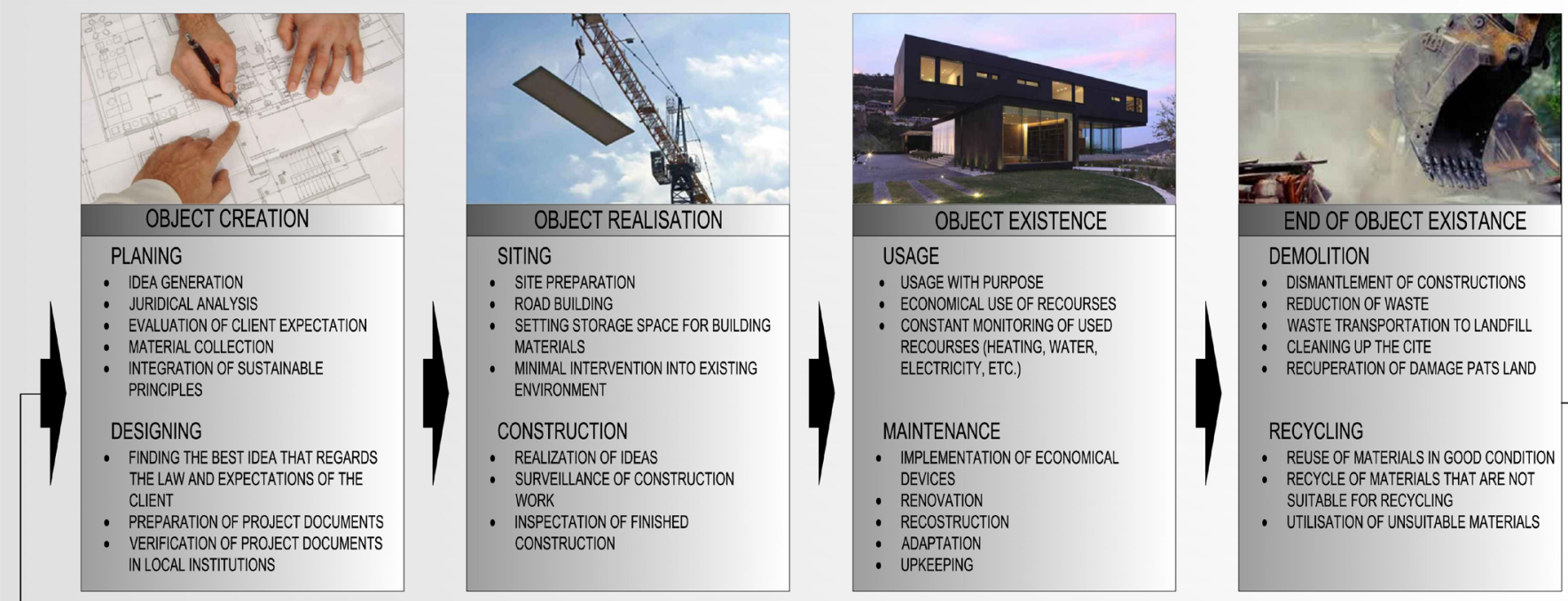

Fig. 3. Sustainable housing construction scheme - principles of sustainability must be followed in the whole life cycle of the project.

1. Social. The main feature of this trend is social sustainability. In this case the low cost is the biggest priority. The analyzed examples include: Murray Grove residential tower constructed from cross laminated timber panels in London (UK), Shed House, Healthy House, and Lios Gorm House built at Scotland's Housing Expo in Inverness (UK) [9] (see Fig. 4).

2. Ecological. The trend is characterized by the use of ecological construction materials (recycled or recyclable materials). The analyzed examples include: House NS built for Scotland's Housing Expo in Inverness, Straw House in London built by Sarah Wigglesworth and two buildings from Lithuania D. Penkinski house and Solar Architecture House [9] (see Fig. 5).

3. Technological. Technological trend is characterized by the usage of newest technologies in order to reach the maximum energy efficiency (i.e. solar panels, air source heating pumps, wind turbines and etc.). The following houses were analyzed: Beddington Zero Energy Development by B. Dunster in London, Upton Square in Northampton (UK), Solarsiedlung House in Freiburg (Germany) and Year Prototype 2015 Haus in Darmstadt (Germany) [9] (see Fig. 6).

4. Economic. The main goal of these homes is to maximize energy efficiency. These houses target the middle class and may not be the cheapest ones. The analyzed examples include: Passive House and Three on Nine House built for Scotland's Housing Expo in Inverness and two Lithuania houses - Passive House in Gulbinai 1 and Passive House in Gulbinai 2 (Vilnius District) [9] (see Fig. 7).

5. Aesthetic. This trend apart from energy efficiency is characterized by expressive design and elaborate composition of colors and volumes. The analyzed examples are: Stealth Terrace House, Flower House, and Skewed House from Scotland's Housing Expo and villa "Sea, sand and wind" in Lithuania [9] (see Fig. 8).

6. Organic. This trend is characterized by plastic forms, technological advancements and exceptional high quality architecture. However, the cost of these houses is very high.
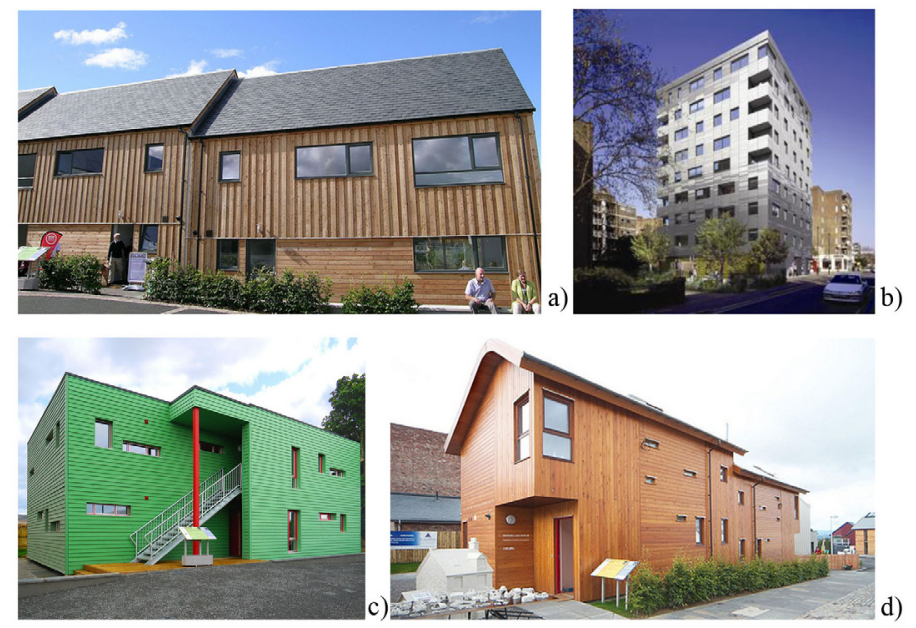

Fig. 4. Social sustainable homes: Shed House (a) [11], Murray Grove (b) [12], Lios Gorm (c) [11], Healthy House (d) [11].
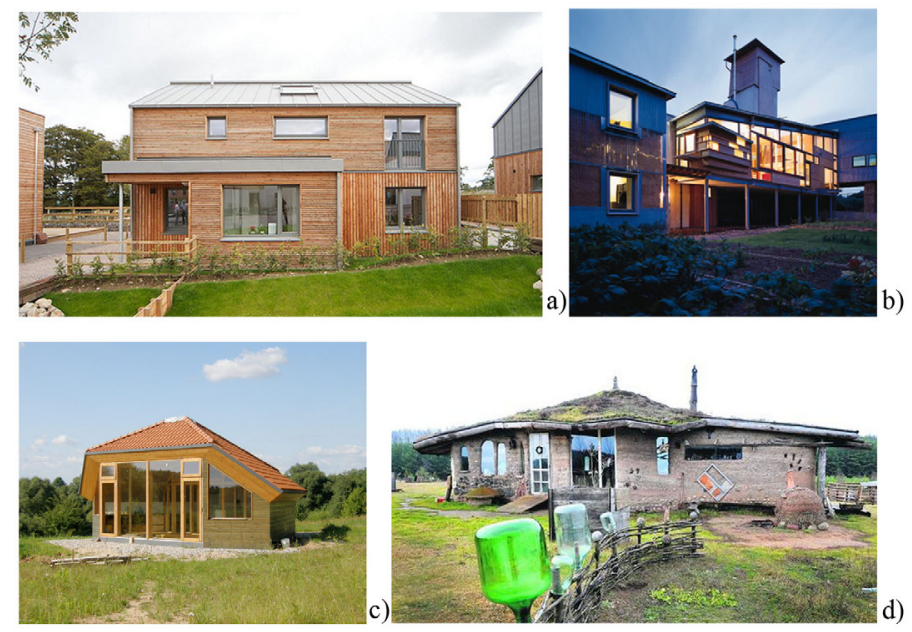

Fig. 5. Ecological sustainable homes: House NS (a) [11], Straw House (b) [7], Solar House (c) [13], D. Penkinski House (d) [14]. 

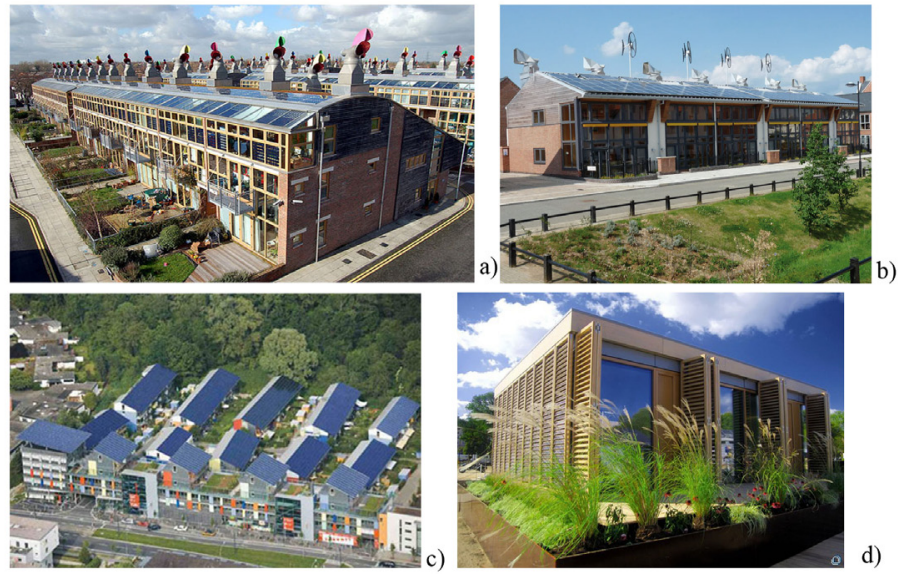

Fig. 6. Technological sustainable homes: BedZED (a) [15], Upton Square (b) [16], Solarsiedlung (c) [17], Year Prototype 2015 Haus (d) [17].
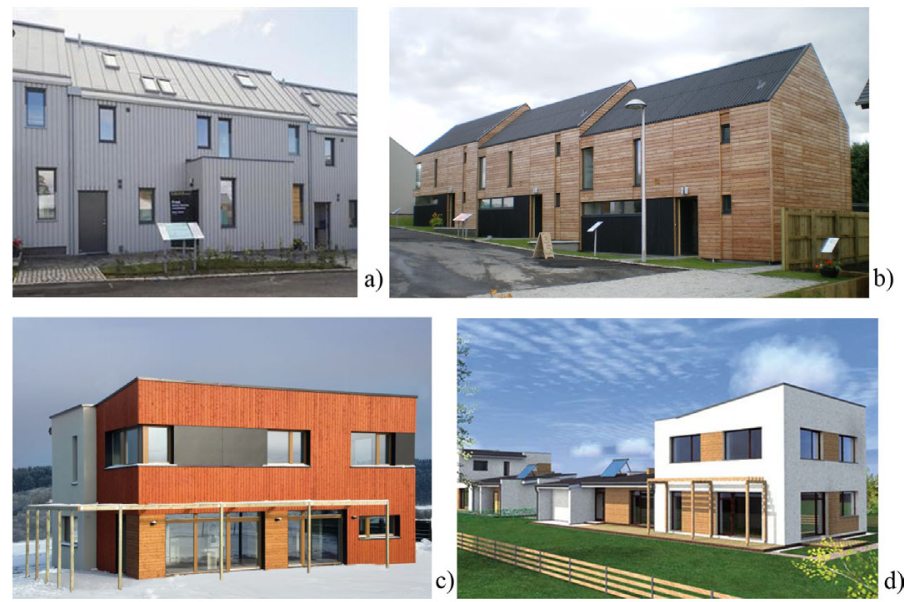

Fig. 7. Economic sustainable homes: Passive House (a) [11], Three on Nine (b) [11], house in Gulbinai 1 (c) [11], house in Gulbinai 2 (d) [18].

\begin{tabular}{|c|c|}
\hline CONTEXTUALITY-I & AESTHETICAL EXPRESSION - ॥ \\
\hline 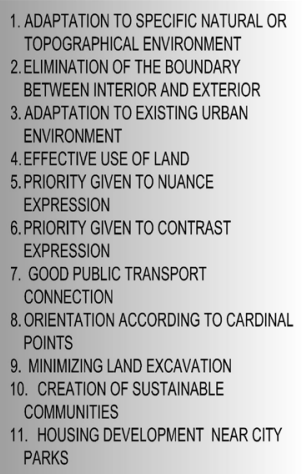 & 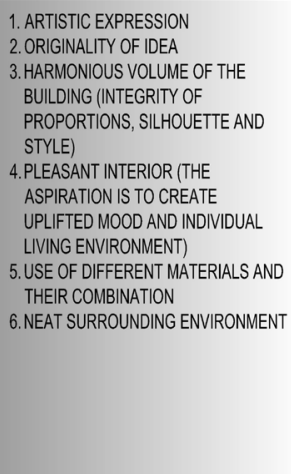 \\
\hline
\end{tabular}

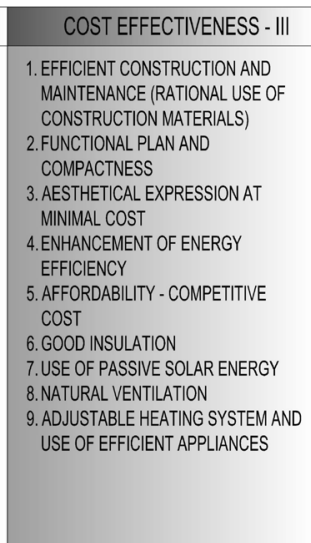

Fig. 10. Analyzed features of sustainable homes.

The analyzed examples of organic residential architecture are well known buildings in Switzerland - Nine Houses in Dietikon, Guldimann House in Lostorf (created by P. Vetsch) and Vals House (created by SeArch), also one house in the United Kingdom Private residence in Bolton [9] (see Fig. 9).

All in all 24 objects were selected according to visual and technical project data and classified into 6 trends of sustainable residential architecture (see Table I).
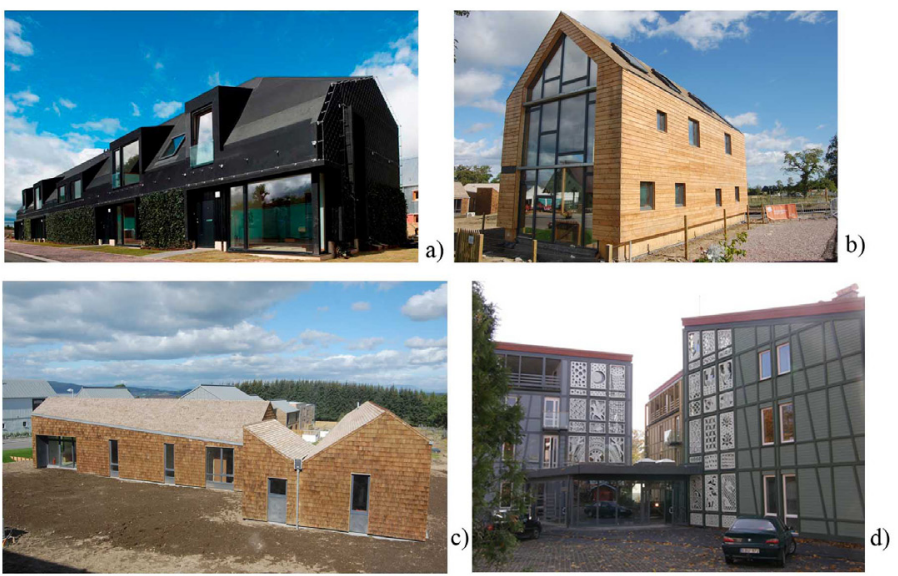

Fig. 8. Aesthetic sustainable homes: Stealth Terrace House (a) [11], Flower House (b) [11], Skewed House (c) [11], villa "Sea, sand and wind" (d) [11].
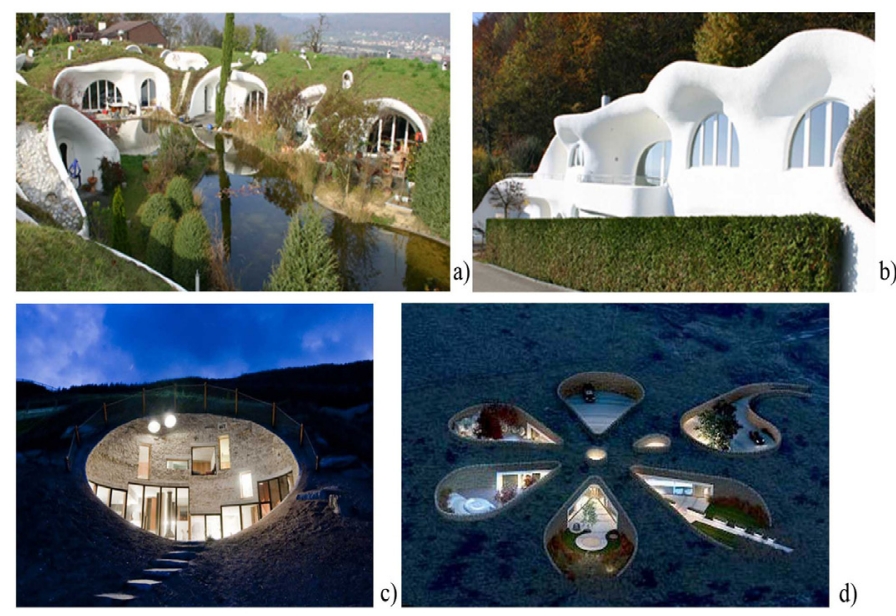

Fig. 9. Organic sustainable homes: Nine Houses (a) [19], Guldimann House (b) [19] and Vals House (c) [20], private residence (d) [21].

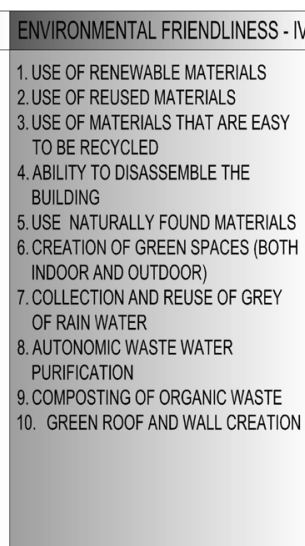

TECHNOLOGICAL INOVATIVITY - VI 1. ADVANCED CONSTRUCTION MATERIALS AND METHODS 2.IMPLEMENTATION OF EXPERIMENTAL PROJECTS

3. USED OF RENEWABLE RESOURCES 3. USED OF RENEWABLE RESOURCES
4. HIGH GOALS FOR ENERGY SAVING (A 4. HND A PLUS APPLIANCES) AND A PLUS APPLIANCES)
5. NEWEST TECHNOLOGIES ARE USED 5. NEWEST TECHNOLOG
FOR ENERGY SUPPLY 6. USE OF ADVANCED AIR CONDITIONING SYSTEMS 7. PROMOTION OF ECOLOGICAL MEANS OF TRANSPORTATION. 
TABLE I

OBJECT OF THE RESEARCH

\begin{tabular}{|c|c|c|}
\hline Trends of sustainable homes & Research objects from abroad & Research object found in Lithuania \\
\hline $\begin{array}{l}\text { Social } \\
\text { It is affordable, low cost housing. However, this } \\
\text { type of housing is not necessarily the most } \\
\text { economical, nor aesthetical. }\end{array}$ & $\begin{array}{l}\text { - Murrey Grow Tower, London, UK } \\
\text { - Shed House, Inverness, UK } \\
\text { - Healty House, Inverness, UK } \\
\text { - Lios Gorm, Inverness, UK }\end{array}$ & None \\
\hline $\begin{array}{l}\text { Ecological } \\
\text { Environmentally friendly, recycled or easily } \\
\text { recyclable materials are used. However, the } \\
\text { ecological building materials do not always } \\
\text { result in aesthetically pleasing design. }\end{array}$ & $\begin{array}{l}\text { - } \text { Strow House, London, UK } \\
\text { - } \text { House NS, Inverness, UK }\end{array}$ & $\begin{array}{l}\text { - Solar architecture house, Babtai } \\
\text { - D. Penkinski house, Vilnius dist. }\end{array}$ \\
\hline $\begin{array}{l}\text { Technological } \\
\text { It is characterized by the usage of newest } \\
\text { technologies in order to reach the maximum } \\
\text { energy efficiency. However this may cause } \\
\text { higher than average construction cost of these } \\
\text { houses and makes them less affordable. }\end{array}$ & $\begin{array}{l}\text { - Bed Zed, London, UK } \\
\text { - Upton Square, Northhampton, UK } \\
\text { - Solarsiedlung, Freiburg, Germany } \\
\text { - Year Prototype } 2015 \text { Haus, Darmstadt, } \\
\text { Germany }\end{array}$ & None \\
\hline $\begin{array}{l}\text { Economic } \\
\text { Houses are usually characterized by cost saving } \\
\text { construction and minimalistic aesthetics. Though } \\
\text { these homes are suited for middle class, they } \\
\text { might not be the cheapest in terms of } \\
\text { affordability. }\end{array}$ & $\begin{array}{l}\text { - The Passive House, Inverness, UK } \\
\text { - Three on Nine House, Inverness, UK }\end{array}$ & $\begin{array}{l}\text { - Passive house in Gulbinai 1, Vilnius dist. } \\
\text { - Passive house in Gulbinai 2, Vilnius dist. }\end{array}$ \\
\hline $\begin{array}{l}\text { Aesthetic } \\
\text { Can be defined by their expressive design and } \\
\text { elaborate architectural design. }\end{array}$ & $\begin{array}{l}\text { - } \text { Stealth Terrace House, Inverness, UK } \\
\text { - } \text { Skewed House, Inverness, UK } \\
\text { - } \quad \text { The Flower House, Inverness, UK }\end{array}$ & $\begin{array}{l}\text { - Villa "Sea, sand and wind" in Joudkrante, } \\
\text { Curonian spit }\end{array}$ \\
\hline $\begin{array}{l}\text { Organic } \\
\text { Houses are characterized by plastic, organic } \\
\text { forms, technological advancement and } \\
\text { exceptional architecture. Such architecture is } \\
\text { usually inspired by natural forms and cosmogy. }\end{array}$ & $\begin{array}{l}\text { - Vals House, Switzerland } \\
\text { - Privat residence, Bolton, UK } \\
\text { - Nine Houses, Dietikon, Switzerland } \\
\text { - Guldimann House, Lostorf, Switzerland. }\end{array}$ & None \\
\hline
\end{tabular}

Contextuality is defined as specific ability of residential building to fit into its surrounding environment (11 subcategories). Aesthetical expression is formulated as aesthetically pleasing architecture (6 subcategories). Cost effectiveness is related to efficient construction and maintenance of the building. Building must be affordable for socially vulnerable groups (10 subcategories). Environmental friendliness is perceived as the use of ecological, recyclable materials (10 subcategories). Psychological acceptability primarily states for physical convenience of the building plan and good space arrangement. Attention is also paid to the scale of overall building volume and height (10 subcategories). Technological innovativity is formulated as the use of advanced technological improvements in building design (7 subcategories), such as photovoltaics, advance construction materials and building methods (see Fig. 10).

All features are evaluated in points from 0 (not defined) to 2 (the most well defined). All calculations in the end are summed up and converted to show the accurate level of expression of each feature. Expression of each feature may vary from very weak (from $0 \%$ to $25 \%$ ) to weak (from $26 \%$ to $50 \%$ ), average (from $51 \%$ to $75 \%$ ) or strong (from $76 \%$ to $100 \%$ ) according to a trend. In the end, the level of exposition of each feature is expressed in certain graphical schemes.

\section{B. Research of Predominant Site Setting}

The aim is to estimate the most suitable site setting for each trend.Estimations are made based on actual setting of each studied building. Three main possible settings were distinguished: city (downtown and highly developed zones), suburban or small town and rural areas [9].

\section{Research of Visual Quality}

Visual quality of each sustainable housing trend is estimated based on the overall impression. During the assessment, the type and level of relationship between architectural composition of the building and its environment are measured. According to J. Saimonds, the value of the building is provided not only by its aesthetical appearance but also by its relationship with other surrounding elements of the environment, such as other buildings and natural components. Based on that, each building plays its role in the creation of visual space and such features as site, size of the building, its relationship with environment become important.

In general, three types of relationship between the building and its surrounding environment can be estimated:

1) building is a part of the background - it blends with the surrounding environment in its shape, materials, color, etc;

2) building is equal to the surrounding environment - it complements the environment, is clearly visible, however does not dominate;

3) building dominates over environment-it can be distinguished in its height, volume, color or other parameters.

Each of these cases becomes significant when all visual elements of the landscape are estimated in order to find out if the building creates architectural composition with its environment or not. Buildings visual quality may be positive, negative or neutral [9]. 
TABLE II

OTHER RESEARCH OBJECTIVES OF SOCIAL TREND SUSTAINABLE HOUSES

\begin{tabular}{|c|c|c|}
\hline Research objective & \multicolumn{2}{|c|}{ Research results } \\
\hline Predominant project setting & \multicolumn{2}{|c|}{ Suburban are as (lower land prices, cheaper to build), also city areas (according to sociological survey) } \\
\hline \multirow{2}{*}{$\begin{array}{l}\text { Visual quality } \\
\text { (type and level of relationship } \\
\text { between the architectural } \\
\text { composition and its environment } \\
\text { is measured) }\end{array}$} & $\begin{array}{l}\text { Assessment of architectural composition } \\
\text { (objective characteristic) }\end{array}$ & $\begin{array}{l}\text { Assess ment of relationship with environment } \\
\text { (subjective characteristic) }\end{array}$ \\
\hline & $\begin{array}{l}\text { Equal to surrounding environment } \\
\text { (these buildings do not dominate nor they are } \\
\text { part of the background; in terms of their scale, } \\
\text { construction type and relationship with environment } \\
\text { they are equivalent elements of the environment - } \\
\text { together with other forms of environmental building } \\
\text { type) }\end{array}$ & $\begin{array}{l}\text { Is neutral in terms of visual quality } \\
\text { Improves visual quality (has positive impact) }\end{array}$ \\
\hline $\begin{array}{l}\text { Relationship between building } \\
\text { and its setting } \\
\text { (visual impact on its surrounding } \\
\text { environment was estimated) }\end{array}$ & \multicolumn{2}{|c|}{$\begin{array}{l}\text { Contrast is not expressed } \\
\text { (these buildings do not dominate or stand out, they harmoniously blend with existing environment using } \\
\text { conventional building materials and construction styles, restraining the scale and proportions) }\end{array}$} \\
\hline Environmental impact & \multicolumn{2}{|c|}{$\begin{array}{l}\text { Neutral (these buildings are not stocked with the most advanced technologies in terms of energy supply, } \\
\text { because that would decrease their affordability; they usually are partially dependent on renewable resources) }\end{array}$} \\
\hline
\end{tabular}

TABLE III

OTHER RESEARCH OBJECTIVES OF ECOLOGICAL TREND SUSTAINABLE HOUSES

\begin{tabular}{|c|c|c|}
\hline Research objective & \multicolumn{2}{|c|}{ Research results } \\
\hline Predominant project setting & \multicolumn{2}{|c|}{$\begin{array}{l}\text { Suburban areas and rural areas (suits best the environmentally friendly way of life and the concept of } \\
\text { vernacular construction) also city area (according to sociological survey) }\end{array}$} \\
\hline \multirow{3}{*}{$\begin{array}{l}\text { Visual quality } \\
\text { (type and level of } \\
\text { relationship between the } \\
\text { architectural composition and its } \\
\text { environment is measured) }\end{array}$} & $\begin{array}{l}\text { Assess ment of architectural composition } \\
\text { (objective characteristic) }\end{array}$ & $\begin{array}{l}\text { Assessment of relationship with environment } \\
\text { (subjective characteristic) }\end{array}$ \\
\hline & $\begin{array}{l}\text { Equal to surrounding environment } \\
\text { (these buildings do not dominate nor they are } \\
\text { part of the background; in terms of their scale, } \\
\text { construction type and relationship with environment } \\
\text { they are equivalent elements of the environment - } \\
\text { together with other forms of environmental building } \\
\text { type) }\end{array}$ & $\begin{array}{l}\text { Reduces visual quality (has negative impact when } \\
\text { building looks inappropriate in its surrounding } \\
\text { environment }- \text { i.e. when it is build from unsuitable } \\
\text { materials (trash or waste) } \\
\text { Is neutral in terms of visual quality } \\
\text { Improves visual quality (has positive impact) }\end{array}$ \\
\hline & $\begin{array}{l}\text { Dominates over surrounding environment } \\
\text { (some of these buildings may dominate in } \\
\text { environment, that depends on architectural idea, } \\
\text { which may be various) }\end{array}$ & Improves visual quality (has positive impact) \\
\hline $\begin{array}{l}\text { Relationship between building } \\
\text { and its setting } \\
\text { (visual impact on its } \\
\text { surrounding environment was } \\
\text { estimated) }\end{array}$ & \multicolumn{2}{|c|}{$\begin{array}{l}\text { Contrast is not expressed } \\
\text { (these buildings do not dominate or stand out, they harmoniously blend with existing environment using } \\
\text { conventional building materials and construction styles, restraining the scale and proportions) }\end{array}$} \\
\hline Environmental impact & \multicolumn{2}{|c|}{$\begin{array}{l}\text { Neutral (these buildings are not stocked with the most advanced technologies in terms of energy supply, } \\
\text { because that would decrease their affordability; they usually are partially dependent on renewable resources) }\end{array}$} \\
\hline
\end{tabular}

D. Research of Relationship Between the Building and its Setting

Here visual impact of each sustainable housing trend on its surrounding environment was estimated. It was important to estimate the relationship between aesthetical expression of each sustainable home and its particular environment (urban or natural). The research was based on a building estimation scheme proposed by V. Jurkštas. He defined the key methods of harmonizing new building with particular environment:

1. Structure and partitions. One of the most important methods, it can be defined by metrical and rhythmical arrangement of the facade. Partitions always give good results, regardless of architectural quality. It can give plasticity, enhance the silhouette, and eliminate the "long house" impression.
2. Scale. This method can be described as harmonious relationship between building height and human scale. Appropriate proportion of this relationship allows the person observe the environment properly.

3. Form and elements. The most popular element of improvisation in residential architecture is roof and its pediment.

4. Environment. The most traditional and distinctive feature of the city development is the combination of various buildings into a single composition. However, the effect of environmental enrichment can appear only under one condition - when a new building is in contrast with its surroundings. Only in this case exceptional architecture can be created [10].

In this research all estimations are expressed in points, 
TABLE IV

OTHER RESEARCH OBJECTIVES OF TECHNOLOGICAL TREND SUSTAINABLE HOUSES

\begin{tabular}{|c|c|c|}
\hline Research objective & \multicolumn{2}{|c|}{ Research results } \\
\hline Predominant project setting & \multicolumn{2}{|c|}{ City area (lower land prices, cheaper to build), also suburban area (according to sociological survey) } \\
\hline \multirow{3}{*}{$\begin{array}{l}\text { (type and level of } \\
\text { relationship between the } \\
\text { architectural composition and its } \\
\text { environment is measured) }\end{array}$} & $\begin{array}{c}\text { Assessment of architectural composition } \\
\text { (objective characteristic) }\end{array}$ & $\begin{array}{c}\text { Assessment of relationship with environment } \\
\text { (subjective characteristic) }\end{array}$ \\
\hline & $\begin{array}{l}\text { Equal to surrounding environment } \\
\text { (these buildings do not dominate nor they are } \\
\text { part of the background; in terms of their scale, } \\
\text { construction type and relationship with environment } \\
\text { they are equivalent elements of the environment - } \\
\text { together with other forms of environmental building } \\
\text { type) }\end{array}$ & $\begin{array}{l}\text { Is neutral in terms of visual quality } \\
\text { Improves visual quality (has positive impact) }\end{array}$ \\
\hline & $\begin{array}{l}\text { Dominates over surrounding environment } \\
\text { (some of these buildings may dominate in } \\
\text { environment, that depends on architectural idea, } \\
\text { which may be various) }\end{array}$ & Improves visual quality (has positive impact) \\
\hline $\begin{array}{l}\text { Relationship between building } \\
\quad \text { and its setting } \\
\text { (visual impact on its surrounding } \\
\text { environment was estimated) }\end{array}$ & \multicolumn{2}{|c|}{$\begin{array}{l}\text { Contrast is expressed strongly (sometimes these buildings may become dominant in the environment, this } \\
\text { can be explained with usage of sophisticated technological advancements, like: photovoltaics, wind turbines, } \\
\text { which look inappropriate in specific downtown or residential areas) }\end{array}$} \\
\hline Environmental impact & \multicolumn{2}{|c|}{ Positive (residential buildings fully use on renewable energy resources) } \\
\hline
\end{tabular}

TABLE V

OTHER RESEARCH OBJECTIVES OF ECONOMIC TREND SUSTAINABLE HOUSES

\begin{tabular}{|c|c|c|}
\hline Research objective & \multicolumn{2}{|c|}{ Research results } \\
\hline $\begin{array}{l}\text { Predominant } \\
\text { setting }\end{array}$ & \multicolumn{2}{|c|}{$\begin{array}{l}\text { Suburban areas and rural areas (suits best the environmentally friendly way of life and the concept of } \\
\text { construction) also city area (according to sociological survey) }\end{array}$} \\
\hline \multirow{2}{*}{$\begin{array}{l}\text { Visual quality } \\
\text { (type and level of } \\
\text { relationship between the } \\
\text { architectural composition and its } \\
\text { environment is measured) }\end{array}$} & $\begin{array}{l}\text { Assessment of architectural composition } \\
\text { (objective characteristic) }\end{array}$ & $\begin{array}{l}\text { Assessment of relationship with environment } \\
\text { (subjective characteristic) }\end{array}$ \\
\hline & $\begin{array}{l}\text { Equal to surrounding environment } \\
\text { (these buildings do not dominate nor they are } \\
\text { part of the background; in terms of their scale, } \\
\text { construction type and relationship with environment } \\
\text { they are equivalent elements of the environment - } \\
\text { together with other forms of environmental building } \\
\text { type) }\end{array}$ & $\begin{array}{l}\text { Is neutral in terms of visual quality } \\
\text { (buildings blend with surroundings) }\end{array}$ \\
\hline $\begin{array}{l}\text { Relationship between building } \\
\text { and its setting } \\
\text { (visual impact on its } \\
\text { surrounding environment was } \\
\text { estimated) }\end{array}$ & \multicolumn{2}{|c|}{$\begin{array}{l}\text { Contrast is not expressed } \\
\text { (these buildings do not dominate or stand out, they harmoniously blend with existing environment using } \\
\text { conventional building materials and construction styles, restraining the scale and proportions) }\end{array}$} \\
\hline Environmental impact & \multicolumn{2}{|c|}{$\begin{array}{l}\text { Neutral (these buildings are not stocked with the most advanced technologies in terms of energy supply, } \\
\text { because that would decrease their affordability; they usually are partially dependent on renewable resources) }\end{array}$} \\
\hline
\end{tabular}

according to visual contrast of each building. The measurements are expressed as follows:

1) Neutral - building is neutral in its surrounding environment (0 points);

2) Nuance - building looks alike in its surrounding environment (1 point);

3) Contrast - building is different in its surrounding environment ( 2 points);

\section{E. Research of Environmental Impact}

The purpose of this estimation was to evaluate environmental impact of each sustainable housing trend. Environmental impact is evaluated according to the usage of renewable resource. Three levels of environmental impact of sustainable homes were estimated:

1) Negative- building fully depends on nonrenewable resources;
2) Neutral - building partially depends on non-renewable resources;

3) Positive - building fully depends on renewable resources;

\section{Results of Sustainable Housing Research}

Research reviled the following results:

1) Social trend -cost effectiveness (100\%) also psychological acceptability (94\%) dominate. These homes are affordable for socially vulnerable groups. They are mostly cottage or apartmenttype buildings. However, these homes are behind in terms of environmental friendliness $(31 \%)$ and technological innovativity (13\%). Advanced technologies are rarely used and ordinary construction materials are applied. This results in an average aesthetical expression. For other features of the social trend see Table II. 
TABLE VI

OTHER RESEARCH OBJECTIVES OF AESTHETIC TREND SUSTAINABLE HOUSES

\begin{tabular}{|c|c|c|}
\hline Research objective & \multicolumn{2}{|c|}{ Research results } \\
\hline $\begin{array}{l}\text { Predominant } \\
\text { setting }\end{array}$ & \multicolumn{2}{|c|}{$\begin{array}{l}\text { Suburban areas (suits best the environmentally friendly way of life and the concept of construction) also city } \\
\text { area (according to sociological survey) }\end{array}$} \\
\hline \multirow{2}{*}{$\begin{array}{l}\text { Visual quality } \\
\text { (type and level of } \\
\text { relationship between the } \\
\text { architectural composition and its } \\
\text { environment is measured) }\end{array}$} & $\begin{array}{l}\text { Assessment of architectural composition } \\
\text { (objective characteristic) }\end{array}$ & $\begin{array}{c}\text { Assess ment of relationship with environment } \\
\text { (subjective characteristic) }\end{array}$ \\
\hline & $\begin{array}{l}\text { Equal to surrounding environment } \\
\text { (these buildings do not dominate nor they are } \\
\text { part of the background; in terms of their scale, } \\
\text { construction type and relationship with environment } \\
\text { they are equivalent elements of the environment - } \\
\text { together with other forms of environmental building } \\
\text { type) }\end{array}$ & $\begin{array}{l}\text { Is neutral in terms of visual quality } \\
\text { Improves visual quality (has positive impact) }\end{array}$ \\
\hline $\begin{array}{l}\text { Relationship between building } \\
\quad \text { and its setting } \\
\text { (visual impact on its surrounding } \\
\text { environment was estimated) }\end{array}$ & \multicolumn{2}{|c|}{$\begin{array}{l}\text { Contrast is expressed averagely (these buildings often have a distinguishing architectural expression, that } \\
\text { may stand out in certain environment, like: style, silhouette, details used, sometimes even color) }\end{array}$} \\
\hline Environmental impact & \multicolumn{2}{|c|}{$\begin{array}{l}\text { Neut ral (these buildings are not stocked with the most advanced technologies in terms of energy supply, because } \\
\text { that would decrease their affordability; they usually are partially dependent on renewable resources) }\end{array}$} \\
\hline
\end{tabular}

TABLE VII

OTHER RESEARCH OBJECTIVES OF ORGANIC TREND SUSTAINABLE HOUSES

\begin{tabular}{|c|c|c|}
\hline Research objective & \multicolumn{2}{|c|}{ Research results } \\
\hline $\begin{array}{ll}\text { Predominant } & \text { project } \\
\text { setting } & \end{array}$ & \multicolumn{2}{|c|}{ Rural areas (suits best the environmentally friendly way of life and the concept of construction) } \\
\hline \multirow{2}{*}{$\begin{array}{l}\text { Relationship between building } \\
\text { and its setting } \\
\text { (visual impact on its } \\
\text { surrounding environment }\end{array}$} & $\begin{array}{c}\text { Assess ment of architectural composition } \\
\text { (objective characteristic) }\end{array}$ & $\begin{array}{l}\text { Assessment of relationship with environment } \\
\text { (subjective characteristic) }\end{array}$ \\
\hline & $\begin{array}{l}\text { Equal to surrounding environment } \\
\text { (these buildings do not dominate nor they are } \\
\text { part of the background; in terms of their scale, } \\
\text { construction type and relationship with environment } \\
\text { they are equivalent elements of the environment - } \\
\text { together with other forms of environmental building } \\
\text { type) }\end{array}$ & $\begin{array}{l}\text { Is neutral in terms of visual quality } \\
\text { Improves visual quality (has positive impact) }\end{array}$ \\
\hline $\begin{array}{l}\text { Relationship between building } \\
\quad \text { and its setting } \\
\text { (visual impact on its surrounding } \\
\text { environment was estimated) }\end{array}$ & \multicolumn{2}{|c|}{$\begin{array}{l}\text { Contrast is not expressed } \\
\text { (these buildings do not dominate or stand out, they harmoniously blend with existing environment using } \\
\text { conventional building materials and construction styles, restraining the scale and proportions) }\end{array}$} \\
\hline Environmental impact & \multicolumn{2}{|c|}{ Positive (residential buildings fully use on renewable energy resources) } \\
\hline
\end{tabular}

2) Ecological trend -cost effectiveness reaches the highest score of $80 \%$, because cheap methods of construction are implemented. Psychological acceptability (66 \%) and environmental friendliness $(60 \%)$ are averagely expressed. It can be explained by the fact that ecological buildings sometimes lack in their design, in addition, waste materials are sometimes used. The latter harms aesthetical expression (46\%). Contextuality is weakly expressed $(50 \%)$, because usually detached houses are designed and that does not create community spirit. Sophisticated technological innovations are barely used $(9 \%)$. For other features of the ecological trend see Table III.

3) Technological trend - technological innovations are very popular (100\%). Cutting-edge construction methods are used, experimental projects are implemented as well. Psychological acceptability (86\%) and cost effectiveness (94\%) are also strongly expressed. However, contextually (73\%) and aesthetical expression (82\%) are averagely expressed. These homes lack expressiveness and artistic taste. Recycled building materials are rarely used. For other features of the technological trend see Table IV.
4) Economic trend - in this trend, cost effectiveness (91\%) and psychological acceptability (80\%) reach the highest score. These buildings are partially implemented using the newest technological advancements and that improves their energy efficiency and lowers heating costs. However, the most advanced technologies and sophisticated construction methods are not used, because that would increase construction and exploitation costs. Due to the same reason aesthetical expression is weak $(40 \%)$. For other features of the economic trend see Table V.

5) Aesthetic trend - in this trend, aesthetical expression (90\%) and psychological acceptability (93\%) are expressed strongly. However, contextually (52\%) and cost effectiveness (61 \%) are averagely expressed. Such results only confirm that individual aesthetical expression of the building is often opposed to low cost idea. Environmental friendliness (40\%) and technological innovativity $(27 \%)$ are weak. The latter can be explained by the fact that technological advancements often contradict with the conviction of aesthetically pleasing architecture. For other features of the aesthetic trend see Table VI. 
6) Organic trend - the most advanced technologies and methods are used in construction. The buildings are exceptionally friendly for the environment and may be characterized by a high degree of aesthetics. However, these homes are often built in remote areas and often do not create the sense of community. Also, the use of innovative technologies increases costs and reduces social availability. The last factor affects contextuality $(65 \%)$ and cost effectiveness $(63 \%)$. For other features of the organic trend see Table VII.

\section{Conclusions}

The research of sustainable houses revealed the following results:

1. Social houses are cheap and affordable. These homes are mostly cottage or apartment-type buildings where the sense of community is created. However, advanced technologies are rarely used in construction.

2. Ecological houses are cheap. However, sometimes they lack in their design: they do not provide panoramic views, do not create community spirit, unacceptable construction materials (garbage, waste) are also used. The latter harms the overall aesthetic expression. Contextuality is weakly expressed (50\%), because usually detached houses are designed that do not create the community spirit.

3. Technological houses are stocked with cutting-edge technologies. However, contextually and aesthetical expression usually suffer. This is often related to sophisticated technological advancements that start to dominate in the surrounding environment. These homes also often lack expressiveness and artistic taste.

4. Economical houses are partially implemented with new technological advancements and that improves energy efficiency. However, the most advanced technologies are not used, because that would increase costs. Aesthetical expression is average. (These residential buildings should not be confused with social homes. Economical sustainable homes are cheap detached houses, more suited for middle class families.)

5. Aesthetical houses have high aesthetical expression and are psychologically acceptable. However, their construction costs are higher than average. That confirms that individual aesthetical expression of the building is often opposed to affordability. Technological innovativity in terms of renewable energy usage is not very common. The latter can be explained by the fact that technological advancements often look inappropriate and contradict aesthetically pleasing architecture.

6. Organic houses use most advanced technologies, are exceptionally friendly to the environment and may be characterized by a high degree of aesthetics. However, they are often built in remote areas and that does not create the sense of community. Also, the use of innovative technologies increases the price of the building and reduces social availability.

7. The research proved that hypothesis is correct. However, there is no ideal direction that will suit all cases, because each trend has its own advantages and disadvantages. Depending on the selected trend, practicing architects can forecast the outcome of particular project and prevent possible problems, which may occur in the future.
8. The survey of predominant project setting revealed that only organic sustainable homes are best suited to be built in rural areas. For aesthetical, technological, social homes the urban or suburban areas are more suitable. The last two directions of sustainable homes (economic and ecological) can be suitable in all settings (both city, suburban and rural areas).

\section{REFERENCES}

1. Wiliams, D. Sustainable Design : Ecology, Architecture and Planning. Hoboken, NJ: John Wiley \& Sons, 2007. 274 p.

2. Wines, J. Green Architecture. Köln: Taschen, 2008. 240 p.

3. Narvydas, A. Hypothetical Principles and Directions of Sustainable Housing. Ecological Architecture 2011. Kaunas: Technologija, 2011, pp. 51-58.

4. Vienna Memorandum on "World Heritage and Contemporary Architecture Managing the Historic Urban Landscape" (WHC-05/15.GA/INF.7, Paris, 23 September 2005) [online]. UNESCO World Heritage Centre [cited 06.07.2012]. http://whc.unesco.org/archive/2005/whc05-15ga-inf7e.pdf

5. Kamičaitytè-Virbašinė, J. Gražulevičiūtè-Vileniškè, I. Premises for development of sustainable architecture in urban environment. Town Planning and Architecture. Vol. 33. 2009, pp. 363-373.

6. Kibert, Ch. Sustainable construction : Green Building Design and Delivery. Hoboken, NJ: John Wiley \& Sons, 2008. 399 p.

7. Sarah Wigglesworth Architects - 9 Stock Orchard Street, Islington, England [online]. Archinovations - Green Architecture Magazine [cited 14.04.2011] http://www.archinnovations.com/featured-projects/houses/sarah-wiggleswortharchitects-stock-orchard-street/

8. Xiging Disctrict Housing Design, Tianjin, China, 2010 [online]. Michael Sorkin Studio [cited 10.07.2012]. http://www.sorkinstudio.com/tianjinII7.htm

9. Kaunas University of Technology, Principles of sustainable housing design (Master final work of A. Narvydas). Kaunas, 2012.

10. Jurkštas, V. The problem of architectural harmonization. Vilnius: Technika, 1994. 200 p.

11. Photo by Arturas Narvydas, 2010.

12. Murray Grove Housing Development, Northeast London, England, UK [online]. E-architect [cited 10.07.2012]. http://www.e-architect.co.uk/ london/stadthaus_murray_grove.htm

13. Saulès architektūra: namas, kurio nereikia šildyti giedrą šaltą dieną [online]. Valstietis [cited 10.07.2012]. http://www.valstietis.lt/Pradzia/Naujienos/ Technologijos/Saules-architektura-namas-kurio-nereikia-sildyti-giedrasalta-diena

14. Molinis Namas : Funkcionuojantis Rankų Darbo Meno Kūrinys [online]. Delfi Tv [cited 10.07.2012]. http://tv.delfi.lt/video/lb5H21U5/

15. BedZED - Beddington Zero Energy Development [online]. Wikipedia [cited 10.07.2012]. http://en.wikipedia.org/wiki/BedZED

16. Upton Square [online]. Arup [cited 10.07.2012]. http://www.arup.com/ Projects/Upton_Square/UponSquare_street.aspx

17. Guzowski, M. Towards Zero Energy Architecture : New Solar Design. London: Laurence King, 2010, 208 p.

18. Pasyvus Namas Verkiuose [online]. Vekmé UAB [cited 10.07.2012]. http:// www.veikme.lt/gyvenamasis_namas/177

19. Earth Houses [online]. Peter Vetsch Architectur [cited 10.07.2012]. http:// www.erdhaus.ch/main.php?fla=y\&lang=en\&cont=earthhouse

20. Villa Vals / SeARCH \& CMA [online]. Arch Daily [cited 10.07.2012]. http://www.archdaily.com/43187/villa-vals-search-cma

21. Bolton Eco House [online]. Make Architects [cited 10.07.2012]. http://www.makearchitects.com/\#/projects/9067/ 


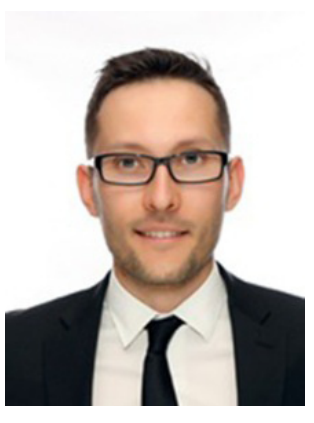

Arturas Narvydas. Bachelor of Architecture, 2010, Master of Architecture, 2012, Kaunas University of Technology, Faculty of Civil Engineering and Architecture, Department of Architecture and Land Management, Lithuania. Currently working on individual practice. Participant of local and international conferences. Active research interests: residential architecture, sustainable architecture and design, affordable social housing.

\section{Contact Data}

Arturas Narvydas

Kaunas University of Technology, Faculty of Civil Engineering and Architecture, Department of Architecture and Land Management

Studentų g. 48, 51367 Kaunas, Lithuania

Phone: +370 37300456 ,

Fax: +370 37451546

E-mail: archiz@mail.com 